(C) 2018 International Journal of Nursing and Midwifery Science (IJNMS)

This is an Open Access article distributed under the terms of the Creative Commons Attribution 4.0 International License which permits unrestricted non-commercial use, distribution, and reproduction in any medium, provided the original work is properly cited.

http://ijnms.net/index.php/ijnms

e-ISSN : 2597-9345

LETTER TO EDITOR

p-ISSN : 2597-761X

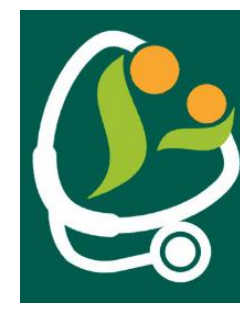

\title{
CHALLENGES AND FIGHTING SOCIAL STIGMA IN PATIENT WITH SCHIZOPHRENIA IN INDONESIA.
}

\begin{abstract}
Amar Akbar*, Lilik MA*, Imam Zainuri*, Kyle Dornhofer**
Mental Health Nursing Department, Bina Sehat PPNI Institute Health of Science, Mojokerto, Indonesia ${ }^{1}$
\end{abstract}

MD Candidate University of California, Irvine ${ }^{2}$

Correspondent email: amar@stikes-ppni.ac.id

Social stigma becomes a crucial issue of mental health of the community, more than $70 \%$ of patients with mental disorders do not receive optimal care in the community mental health service system causes include: people do not like the characteristics of mental disorders ranging from mild to severe, slow in access treatment in mental disorders where people assume people with mild mental disorders can still adapt well, people also feel hopelessness in patients who have been associated in a psychiatric hospital and have been convicted of serious mental disorders can not re-adapt to society (Henderson, Evans-Lacko, \& Thornicroft, 2013), in indonesia social stigma becomes factors that affected mental health called "Pasung", pasung known as physical renstrain patient with mental disorder in community field in indonesia.
Psychological factors, emotions and feelings, and stereotypes in women are also the spirit of self-stigma in women is higher. Men, this factor is also related to the traditional culture of society as well as the common sense that developed in the community, the symptoms of a person's mental disorder increases his stigma, while education and good selfimage can degrade the stigma of people with mental disorders (Girma et al., 2013).

Interventions that can be done by health workers in reducing stigma include Increasing public knowledge about psychiatric disorders, Social contactbased interventions can be done on youth and

school groups and communities to form profitable knowledge, socioeconomic factors are very severe in poverty eradication. special attention (Thornicroft et al., 2016). 
In the case of schizophrenia and depression that must be done to the community group and should pay attention to changes in this stigma becomes more effective (Pescosolido, Medina, Martin \& Long, 2013), in .

Personal stigma in patients with mental disorders will have a negative impact on the condition of the disease, the patient is more aggressive and disrespectful in society and more closed in the access of public information, in fact the promotion and empowerment of patients with mental disorders can diminish the stigma of the patient self, the challenge of program development to solve the problem This stigma is a challenge for governments and health workers to innovate in policy making (Corrigan, Kosyluk, \& Rüsch, 2013).

Empowering people with mental disorders through social intervention can reduce the side effects of antipsychotic drugs and simultaneously help selfstigma in people with mental disorders. (Girma et al., 2013). Social intervention in patient with schizophrenia in Indonesia cannot conduct well, its caused intervention for the patient still based on hospitalized are, and very limited in community area.

\section{REFFERENCE}

Corrigan, P. W., Kosyluk, K. A., \& Rüsch, N. (2013). Reducing selfstigma by coming out proud. American Journal of Public Health,
103(5),

794-800.

http://doi.org/10.2105/AJPH.2012.

301037

Girma, E., Tesfaye, M., Froeschl, G., Möller-Leimkühler, A., Dehning, S., \& Müller, N. (2013). Facility based cross-sectional study of self stigma among people with mental illness: towards patient empowerment approach.

International Journal of Mental Health Systems, 7(1), 21. http://doi.org/10.1186/1752-44587-21

Henderson, C., Evans-Lacko, S., \& Thornicroft, G. (2013). Mental illness stigma, help seeking, and public health programs. American Journal of Public Health, 103(5), 777-780.

http://doi.org/10.2105/AJPH.2012. 301056

Pescosolido, B. A., Medina, T. R., Martin, J. K., \& Long, J. S. (2013). The "backbone" of stigma: Identifying the Global core of public prejudice associated with mental illness. American Journal of Public Health, 103(5), 853-860. http://doi.org/10.2105/AJPH.2012. 301147

Thornicroft, G., Mehta, N., Clement, S., Evans-Lacko, S., Doherty, M., Rose, D., ... Henderson, C. (2016). Evidence for effective interventions to reduce mentalhealth-related stigma and discrimination. The Lancet, 387(10023), 1123-1132. http://doi.org/10.1016/S0140-

6736(15)00298-6 Surabaya. 
International Journal of Nursing and Midwifery Science (IJNMS), Volume 2, Issue 1, April 2018 